Johnson bill, then before Congress. This earned him the enmity of the liberal wing of atomic scientists who regarded this bill as militaristic. The May-Johnson bill was vetoed by President Truman and later the Atomic Energy Commission of the McMahon bill came into being. Conant was appointed a charter member of its General Advisory Committee which, for several years to follow, was a very influential group chaired by Oppenheimer. He joined the latter in opposing crash development of the 'super', the hydrogen bomb. When Oppenheimer was threatened with the loss of his military security clearances, being accused of indiscretions such as friendship with some members of the American Communist party, by the military and civilian proponents of the $H$-bomb, led by Edward Teller, Conant took a strong stand and testified on Oppenheimer's behalf at the scandalous hearings before an AEC security board that led to Oppenheimer's dismissal.

Conant became convinced during the war that to insure social progress the Federal Government in peacetime must finance basic scientific research in academic institutions and not do it through its military agencies, because of their secrecy requirements and emphasis on short range goals. At Harvard he established the rule that all faculty research must be open to publication thus closing the doors to most military research contracts. In Washington he took an active part in Congressional hearings which eventually led to the establishment of the National Science Foundation in 1949. Conant became the chairman of its policy-making body, the National Science Board. There he played an important role in the development of NSF policies and procedures in support of basic research which have largely survived to this day.

Conant was offered and accepted the nomination to the presidency of the National Academy of Sciences. However, the liberal elements among atomic scientists disapproved of his stand on the bombing of Japan and his position on the structure of the atomic energy agency. Other elements of the scientific community, including those who were attacking Oppenheimer, were resentful of Conant because of decisions he took in the course of his firm leadership of NDRC and the Manhattan project. Discovering the coalescence of these enmities into open opposition Conant withdrew his candidacy, to a grave disappointment of his many friends. Two years later he retired from the presidency of Harvard, to be appointed United States High Commissioner for Germany and this signaled the end of all his ties with the scientific community.

For four years, as the High Commissioner and then the Ambassador in Bonn, Conant worked effectively with Konrad Adenauer to transform defeated Germany into the Federal Republic, a cornerstone of the NATO alliance.

Sensing this task accomplished Conant returned to the United States in 1957 to embark on the last major career of his extraordinary life. While as president of Harvard he wrote and spoke frequently on problems of college education, Conant turned now to American high schools, assisted by a grant from the Carnegie Foundation. That happened at the time of the Sputnik when doubts about the adequacy of American education were rampant in the United States.

Two years later his book The American High School came out and soon more than 250,000 copies of it were in circulation. The book contained explicit recommendations for improving education and Conant embarked on nationwide travels strenuously campaigning for these reforms.

In 1961 Conant published an angry book Slums and Suburbs, in which, well ahead of the widespread unrest of the late sixties, he warned that the growing numbers of school dropouts and other unemployed urban youths in congested slums constituted a growing charge of social dynamite. This book caused Conant to be attacked by many black leaders because he advocated jobs ahead of school integration. As Conant notes in his autobiography his mistake was not to seek 'alliance with those black leaders who found my book objectionable.'

Two years later came the publication of his last book of this period, The Education of American Teachers, dealing with what he regarded as their scandalously low educational standards. As Conant anticipated the entire school teachers' establishment rose in arms to attack him furiously, but some reforms did follow later.

Prior to final retirement Conant spent two years in West Berlin as the advisor to that city's government, on an educational project financed by the Ford Foundation, and then returned to the United States to have a second look at public schools and publish his findings. Altogether he wrote ten books dealing with public education in addition to those on chemistry. He died in Hannover, New Hampshire, his summer home.

What remains now is the astonishing record of a man who lived many lives and achieved much in each. Conant was one of the principal architects of the American scientific edifice. He combined inborn conservatism with great intellectual boldness and the courage of his convictions when dealing with educational problems. As a high level manager of $R \& D$ he had an unerring feeling for what was right and wrong. He was a cool Yankee and yet could be a warm friend. The presence of Jim Conant made an indelible mark on this century's America.

G. B. Kistiakowsky

\section{G. J. Bramwell}

Geoffrey John Bramwell, Lecturer in Pharmacology in the Department of Pharmacy, Nottingham University, died of leukaemia on 13 April 1978, at the age of 31. Born at Leamington Spa, he was educated at Warwick School and the School of Pharmacy, London, where he graduated in 1969 with a B.Pharm.(Hons) and then went on to work for a Ph.D. (University of London) which he received in 1973. He spent two years as a Research Fellow in the Department of Pharmacology, University of Birmingham, before moving to Nottingham in 1974 .

Geoff Bramwell's research work centred on the pharmacology of neurones in the central nervous system and he was interested in the interactions between neurotransmitter substances and drugs with central effects, utilising the technique of microiontophoresis. His early work in Donald Straughan's department at the School of Pharmacy, was to investigate the actions of drugs on 5-hydroxytryptamine-containing neurones in the brain, particularly cells in the raphe nuclei. The drugs he studied included LSD and, although this work resulted in only a small number of publications, he made a significant contribution in this area. On moving to Birmingham. Bramwell became involved in studies on the actions of opiate drugs on single neurones in the brain and he continued this work at Nottingham after first setting up a laboratory for electrophysiological studies. He extended his studies to include the opioid peptides and latterly became interested in the quantitative aspects of neuronal responses to locally applied pharmacological agents. He published in the British Journal of Pharmacology, Brain Research and Neuropharmacology, and his work was becoming known internationally at the time of his death.

Very few of his friends and colleagues knew of his illness and, in spite of the difficulties caused by the therapy, he remained cheerful and was strenuously trying to keep his research work going. $\mathrm{He}$ is survived by his wife, Alison.

P. B. Bradley 